Narratives of promise, narratives of caution:

\title{
A review of the literature on Social Impact Bonds
}

(Accepted for publication in Social Policy \& Administration June 2016)

\section{Authors}

*Dr Alec Fraser, Research Fellow, Department of Health Services Research \& Policy, London School of Hygiene \& Tropical Medicine. alec.fraser@1shtm.ac.uk

Ms Stefanie Tan, Research Fellow, Department of Health Services Research \& Policy, London School of Hygiene \& Tropical Medicine. stefanie.tan@1shtm.ac.uk

Dr Mylene Lagarde, Senior Lecturer in Health Economics, Department of Health Services Research \& Policy, London School of Hygiene \& Tropical Medicine. mylene.1agarde@1shtm.ac.uk

Professor Nicholas Mays, Professor of Health Policy, Department of Health Services Research \& Policy, London School of Hygiene \& Tropical Medicine. nicholas.mays@1shtm.ac.uk

*Corresponding Author

\section{Acknowledgements}

This work was funded by the Policy Research Programme of the Department of Health for England via its core support for the Policy Research Unit in Policy Innovation Research (PIRU, http://www.piru.ac.uk/). This is an independent report. The Department of Health had no role in writing the paper, and the views expressed are not necessarily those of the Department. We would like to thank members of our wider research team and the project advisory group for their helpful comments on earlier drafts of this review and their suggestions for further reading - in particular, Pauline Allen, Chris Giacomantonio, Julian Le Grand, Megan Sim, Michael Spackman and Mildred Warner. 


\section{Abstract}

Social Impact Bonds (SIBs) are a new mechanism for delivering public services. This paper reviews the emerging SIB literature in high-income settings. It identifies three distinct narratives: a public sector reform narrative; a financial sector reform narrative; and a cautionary narrative. These are analysed relative to three themes: public versus private values; outcomes contracting; and risk allocation. The first two narratives are complementary and offer a 'win-win' portrayal of SIBs. The third narrative challenges this dominant commentary by highlighting potential risks. There is limited empirical evidence on active SIBs to support these narratives. SIBs may have the potential to align public and private interests while improving outcomes for people affected by entrenched social problems, but this is yet to be established and appears less probable than the third more cautionary narrative. More empirical research is needed to consider the potential risks, drawbacks, benefits and alternatives of SIBs in different settings.

\section{Keywords}

Social Impact Bonds, Public sector reform, Outcomes-based performance management, Social Entrepreneurship 


\section{Introduction}

Social Impact Bonds (SIBs) are a new mechanism for the delivery of public services. SIBs usually involve four different parties: commissioners - normally central or local government bodies responsible for ensuring relevant services are made available to target populations; service providers who will deliver the services commissioned; external investors who cover (all or some of) the upfront costs of service provision, in exchange for a commitment by commissioners to re-pay their initial investment plus a return if pre-defined target outcomes are achieved; and specialist intermediaries who are often involved in developing the project, securing the contract with commissioners, facilitating investment and managing the project's delivery. Given the emphasis on outcomes, a SIB contract can specify the appointment of an independent evaluator responsible for measuring the effects of the intervention provided to the target population compared with a control population not receiving the service.

The term 'Social Impact Bond' is misleading. SIBs do not follow the financial logic of a 'bond', as the return is contingent, rather like equity, on the outturn of the projects being financed. And there is as yet no indication that any significant financial market for SIBs may develop between financiers, after the project is initially established. SIBs frequently focus on the prevention or reduction of challenging social problems - for example, reducing crime through targeted anti-recidivism programmes - as in Peterborough in the UK (Disley et al, 2011) and Rikers Island in the US (Rudd et al, 2013), reducing youth unemployment rates by improving young people's skills, as in Nottingham and London in the UK (DWP, 2014), Utah in the USA, and Rotterdam in the Netherlands (Goodall, 2014) or reducing loneliness 
amongst the elderly through befriending schemes as in Worcester in the UK (Tan et al, 2015). The emphasis on prevention relates in large part to the idea that all or part of the payout by the public commissioner to the investor will be funded from actual or hypothetical 'savings' in public service budgets generated by improving outcomes (e.g. lower recidivism rates will accrue savings in police, courts, prison, probation, etc.). Those who invest may be seeking a financial or social return on their investment - in reality these goals may or may not be aligned. Opinion is divided with both enthusiasm and caution around the potential that SIBs may hold for financing complex social interventions and reallocating performance and financial risk from the public towards the private sector. For some, the SIB represents, in theory, a solution to postulated public sector sluggishness by introducing private sector entrepreneurship and linking the traditionally separate private financial and social services sectors (Mulgan et al, 2011; Cohen, 2011). For others, it represents the worst of both sectors, involving the 'financialization' (a process whereby both macroeconomic and public policymaking are subordinated to financial sector interests) of the public sector (Lake, 2015; Dowling and Harvie, 2014) and perverse incentivisation of the philanthropic and non-profit sectors to pursue commercial interests over their social missions (McHugh et al, 2013), as well as the risk that the public sector will encourage commercial investors to make social investments by offering excessively generous terms. Moreover, it is possible that the subcontracted service will be suboptimal compared to a publicly provided service (Mullins et al, 2011).

There are now 32 active SIB projects in the UK (Cabinet Office, 2016), and over 100 other SIB projects have been planned or started around the world (Vanderwal, 2015) since the first SIB was launched at Her Majesty's Prison Peterborough in the UK in 2010. There is significant international policy interest in SIBs, and a growing commentary is emerging about 
SIBs from proponents, participants, observers and critics. SIBs have split opinion since they emerged from UK Prime Minister Gordon Brown's Council on Social Action in 2007. This paper comprehensively reviews the theoretical and empirical academic, and 'grey' literature on SIBs for the first time, and provides a 'Critical Interpretive Synthesis' (Dixon-Woods et $a l, 2006)$ of the emerging concepts and narratives that underpin this developing policy area. The review explores two research questions. Firstly, what are the main themes and concepts within the emergent literature on SIBs? Secondly, what broader theories, or lines of argument, do different groups writing about SIBs in recent years draw upon?

\section{Methods}

Both academic and 'grey' literature were included since this is a novel field and it was important to synthesise as much of the available literature as possible. Following an initial discussion amongst the research team, and an informal review of pieces of 'grey' and academic literature about SIBs already known to the team, two search strategies were used to locate the remaining literature. Firstly, a list of search terms was devised to include the different labels used internationally for SIBs. These terms were then used to search a selection of electronic databases chosen for their coverage of both academic and grey literature. Details of the search terms and databases are given in Table 1.

\section{Insert table 1 about here}

The search was conducted in March 2015 with no time or language filters. No non-English language papers were found. Nothing was found published before 2009. Overall 51,293 references were retrieved. Of these, 406 deemed potentially relevant based on their titles were downloaded into Endnote and duplicates were removed. The abstracts and key words of these 
406 papers were read and screened through April and May 2015 allowing the exclusion of: (1) articles that did not refer to SIBs or any of our other search terms in their title, abstract or key words; (2) those that focused on related concepts (e.g. impact investing, Development Impact Bonds) but did not refer to SIBs or other similar terms in the body of the text. For example, we chose to focus on high-income countries' experiences because their actors and social problems are significantly different from low or middle-income countries thus reducing the relevance of Development Impact Bonds; and (3) those which referred to SIBs or related terms in the body of the text but were considered not to be analysing SIBs in sufficient depth when reviewed by two members of the research team (AF and ST). For example, a number of sources referred to SIBs only in passing (i.e. on fewer than three occasions in the text). Based on this screening, we identified a total of 87 papers for synthesis, comprising 34 academic articles and 53 pieces of 'grey literature'.

We performed a further search based on the reference lists of these 87 selected papers and also received additional recommendations from experts which identified a further 14 papers (4 academic and 10 'grey') giving a total of 101 references (38 academic and 63 grey literature papers). Two members of the research team then read each paper. Since this was primarily an interpretive and conceptual review of a new field, there was no assessment of the quality of studies. From each paper, we extracted information on the place and date of publication, main focus, study design (where empirical), methods used and key points made. Through an iterative process of reading, re-reading and discussing the included primary sources, a number of themes, concepts and narratives began to emerge which were intellectually linked to broader theories of New Public Management (NPM) (Hood, 1991; Ferlie et al, 1996) and Social Entrepreneurship (Porter and Kramer, 2006; Bugg-Levine and Emerson, 2011). 
Results

\section{Description of studies identified}

All 38 academic papers identified (see Appendix 1 for a table showing the different narratives which these publications develop) were very recent (published since 2011), with the majority emanating from English speaking countries (23 from the US, 11 from the UK, three from Canada, and one from Australia). Likewise, the 63 'grey' sources (see Appendix 2 for a table showing the different narratives and the sectors from which these publications emerge) were very recent, all published since 2010. The vast majority of these came from the UK (38) and the US (16). The grey sources included publications by think tanks (8), consultancies including practitioner, intermediary and investment organisations such as Social Finance, an intermediary organisation involved in promoting and running SIBs in the UK (13), government, or government affiliated organisations (14), civil society organisations, including charities (6) and others - e.g. non-peer reviewed academic reports and speeches (8). The majority of papers - both academic and grey - described or commented on SIBs in theoretical terms. There were however, 14 publications (mostly located in the 'grey' literature) describing the early implementation of SIBs or characteristics of SIBs (See Appendix 3 for a table summarising the empirical research). Of the 13 qualitative sources on active or proposed SIBs, 9 were from the UK, 3 from the US and 1 from Australia. We found just one quantitative study reporting on SIB outcomes. 
We identified three major themes in the literature. The first relates to competing public and private values. Whilst the concept of competing public and private values is contested and dynamic in both theoretical and ideological terms (Noordegraaf and Abma, 2003), 'public values' (Beck Jørgensen \& Bozeman, 2007) and 'private values' (Watson et al, 2004) have been analysed across organisations. Empirical comparative work by Van Der Wal et al (2008) identified both differences and similarities between values espoused within public and private sector organisations in the Netherlands. They found that: "lawfulness' , 'impartiality' and 'incorruptibility' were considered the most important public sector values and were absent from business' [private sector's] top values. 'Profitability' and 'innovativeness' were at the top of business values and absent from the public sector's top values. 'Profitability' according to this measure could even be considered the least important public sector value.' (Van Der Wal et al, 2008; p473). SIBs (through both new funding mechanisms and new service delivery relationships) may challenge not only the values supporting the historic ways in which services have been delivered by public, non-profit and voluntary providers (through clearer outcomes specifications), but also the logics and normative assumptions of the private financial services sector (Moore et al, 2012; Nicholls and Murdock, 2012). This raises questions about the extent to which the public sphere should be influenced by private sector values such as profitability and aligned techniques for resource allocation such as competition, market incentives, diversity of providers and new forms of investment, and, in turn, whether the dominant values and resource allocation techniques of the financial services sector should be reoriented towards more socially minded, 'blended returns' rather than traditional profit maximisation.

The second theme relates to the introduction of, or increased primacy given to, outcome measurement in public services' contracting as a result of financing mechanisms like SIBs. 
Whilst there are conflicting views about the utility derived from, and the impacts of, new regimes of measurement outside the SIB literature, both proponents and critics of SIBs tend to be in broad (though not universal) agreement about the potential benefits of a shift to outcomes-focused measurement. The third theme relates to the transfer and calculation of risk amongst different actors through SIB mechanisms, and the ideological and practical implications that this may have for specific services and policy more broadly.

Through the interrogation of these themes, we identified emerging 'lines of argument' (Dixon-Woods et al, 2006); that is, broader, theoretically distinct narratives that differentiate the approaches taken by groups of authors and policy actors. This was a reflexive, iterative process and involved going beyond the SIB-specific texts into the wider theoretical literature in accordance with the principles of interpretive synthesis (Dixon-Woods et al, 2006). We identified three theoretically distinct narratives about SIBs: a public sector reform narrative located within broader theories of NPM; a private financial sector reform narrative located within broader theories of Social Entrepreneurship; and a cautionary narrative sceptical of public and financial sector developments such as NPM and Social Entrepreneurship, and thus of SIBs. There are some significant elements of convergence between the first two narratives (see Appendix 2) which dominate the grey literature and highlight the political salience of SIBs and how they have come to be seen as 'win-win' options by some proponents, particularly in the context of public sector financial austerity in the UK following the 2008 financial crisis. In contrast, the third cautionary narrative was more prevalent within the academic literature, and diverges from the first two by taking a more critical view of SIBs on pragmatic and ideological grounds (see Appendix 1). These three narratives are described and explored in relation to the three themes of values, outcomes measurement and risk, identified above. 


\section{The public sector reform narrative}

This narrative starts from the premise that public, non-profit and voluntary sector organisations have important shortcomings in terms of service design, delivery and accountability, and have so far been unable to find solutions to entrenched social problems. Public sector reform advocates therefore promote the application of private sector management techniques and values, such as introducing market incentives and 'market discipline' to remedy these issues (Mulgan et al, 2011; HM Government, 2011; 2013; Liebman, 2011). From this perspective, SIBs relate to a belief in the exposure of more activities to competitive tendering and the application of private sector-influenced audit systems (Power, 1999), as well as the fostering of entrepreneurship in the public sector (Osborne and Gaebler, 1992). For example, Ronald Cohen, one of the main UK advocates of SIBs, argues that '[S]ocial enterprise and impact investment could dramatically change the role of the social sector in the way that venture capital and business entrepreneurship did in mainstream business in the 1980s and 1990s' (Cohen, 2011). Whilst this view aligns with 'pro-market' and NPM values (Hood, 1991; Ferlie et $a l, 1996$ ), SIBs (as part of a broader trend towards innovation in service delivery and socially-minded investment) go further by creating the space for the potential symbiosis between the public, private, non-profit and voluntary sectors. For example, Callanan and Law (2012), in a report produced by McKinsey \& Company, amongst the earliest such reports from the consultancy sector, emphasise that social innovation occurs 'at the intersection of the public, private, and social sectors.' From this perspective, the opportunity offered by SIBs to merge public and private values is seen as advantageous. 
The public sector reform narrative presents SIBs as an extension of outcomes-based contracting and payment for performance in public services (Lagarde et al, 2013). The aim of outcomes-based contracting is to incentivise managers and service providers through performance pay or outcomes payments which reflect the extent to which pre-agreed metrics of success are achieved. Thus, SIB contracts create a mechanism to improve the ways in which non-profit and voluntary sector organisations measure their performance (Cox, 2011; Liebman, 2011), and, in theory, they introduce greater accountability between commissioners and service providers by setting clearer expectations of what funds will be used to achieve (Stoesz, 2014). Grey literature produced by individual charities and umbrella groups emphasises how SIBs may offer them strategic opportunities to innovate, collaborate, and capitalise upon the changed economic and policy context following the banking crisis of 2008 and subsequent public spending cuts through increased engagement with intermediary organisations, and a focus on outcomes and measurement on the part of commissioners (Fitzpatrick \& Thorne, 2010; Griffiths \& Meinicke, 2014; Joy et al, 2011; Seymour, 2010; Roberts, 2013; Thomas, 2013; Eames et al, 2014). Outcomes-based contracts tend to be longer-term than the traditional block service contracts offered directly to service providers, so a proposed advantage of SIBs is that they offer more financial stability to non-profit and voluntary sector organisations delivering these services. Moreover, as the contracts are outcomes-, not process-based, it is said that they can lead to increased innovation and greater personalisation of services (Social Enterprise UK, 2013; Leventhal, 2012; Jackson, 2013; Clark et al, 2014).

The public sector reform narrative also highlights the potential for SIBs to transfer the financial risk of failure for interventions - that might otherwise be seen as too experimental or risky for traditional forms of public funding - from the state to private/social investors. 
This is said to be appealing as the state does not need, in theory, to release any public funds unless projects demonstrate success and, even then, payments should come out of savings to public budgets as a direct result of the SIB-financed intervention through the prevention of ‘downstream’ social problems (Mulgan et al, 2011; Social Finance, 2011b; Callanan and Law, 2012; Rotheroe et al, 2013). This argument is frequently articulated in UK government publications, which particularly stress the potential virtues of SIBs by emphasising how they may foster innovation, and prevent, or ameliorate complex social problems. These potential benefits are seen as particularly salient in the contemporary policy climate given the current cuts in public spending on public services in the UK (Griffiths \& Meinicke, 2014; Dodd and Moody, 2011; Jackson, 2013; Young Foundation and NESTA, 2011), because SIBs have the potential to transfer risk from the public sector to the private sector (HM Government, 2011; 2013; Cabinet Office, 2013).

The private financial sector reform narrative

The financial sector reform narrative adopts the perspective of private actors. It proposes that blending public and private values will offer private sector actors (particularly financial institutions) an opportunity to effect socially worthwhile change through Social Entrepreneurship whilst simultaneously pursuing commercial interests (Social Investment Task Force, 2010; Cohen, 2011; Leibman, 2011; Mosenson, 2013; Nicholls and Murdoch, 2012; Moore et al, 2012). Advocates of Social Entrepreneurship see this as part of a wider move toward more socially responsible investment and business practices globally (Porter and Kramer, 2006; Bugg-Levine and Emerson, 2011). Through a demonstration of its social usefulness, it is argued that the anti-social, dangerous aspects of financial capitalism may be offset (Shiller, 2013), and SIBs may enable investors to improve their public image (Barajas 
et al, 2014). Whilst this aligns with conventional notions of Corporate Social Responsibility (CSR), Social Entrepreneurship's proponents and observers suggest that there needs to be a more fundamental cultural change in approaches to investment, to which SIBs could contribute (Nicholls, 2013). Social impact investing through SIBs also offers a new potential revenue stream for private financiers (Wilson, 2014). If and where SIBs might prove to be effective, they will also supply investors with a return on their investment, which, whilst theoretically being based on 'savings', nevertheless comes from public funds. Thus the private financial sector could gain access to more public funds in a similar way to the Private Finance Initiative (PFI), a type of contract popular in the UK introduced in the 1990s allowing private finance to fund capital investment in public infrastructure projects (e.g. new hospitals and prisons) (Sussex, 2001) and other mechanisms of private contracting for public services. The commentary on SIBs suggests that such access to public revenue streams could be made lucrative if they were included in risk-adjusted portfolios destined for the social or impact investment market (Lehner \& Brandstetter, 2014).

The financial sector reform narrative emphasises the expertise that new players such as management consultancies and specialist intermediaries, in particular, may bring in linking public, private, non-profit and voluntary sector actors for a fee. These intermediaries are seen as crucial to the implementation of SIBs (Bafford, 2012; Haffar, 2014). For example, they are expected to bring enhanced data monitoring techniques and skills to non-profit and voluntary sector providers which have traditionally been thought to have limited capacity to monitor their own behaviour and validate achieved outcomes (Callanan and Law, 2012). The central importance of extensive, ongoing performance monitoring and concurrent independent evaluation by external actors is emphasised in the literature by many authors as a way of 
ensuring that outcome payments are earned in a valid and attributable way (Cox, 2011; Burand, 2012; Leventhal, 2012; Nicholls, 2013).

The financial sector reform narrative further articulates a strong desire to see the social impact investment market ‘grow' (HM Government, 2011; 2013; Liebman, 2011; Cohen, 2011; Clark et al, 2014). However, there is a distinction between those who see SIBs as a niche for pro-social investors who will take higher risks and smaller returns in contrast to those who desire guaranteed returns or higher yields in the evolving social investment field. A number of authors suggest that if social investment and social entrepreneurship are to grow beyond their niche status, there needs to be greater standardisation in how social impact is measured, communicated, and assessed for risk (Antadze and Wesley, 2012; Nicholls, 2013), for example, through the use of instruments such as the Global Impact Investing Rating System, and Impact Investing and Reporting Standards (Bugg-Levine and Emerson 2011). Liebman (2011), a key proponent of SIBs, sees them as an 'impact first' opportunity for potential investors (in which the primary aim is a social return on investment), rather than a 'finance first' opportunity (in which the primary aim is a financial return on investment). Nevertheless, a significant strand of this literature focuses on how the risk to investors can be made sufficiently attractive to incentivise them to invest in the nascent market. These discussions focus on ways to reduce the level, and uncertainty, of the risk to investors (Bafford 2012, Cox 2011; Burand 2012; Leventhal 2012; Dagher 2013; Shiller 2013). 
In contrast to the generally positive public sector and private sector reform narratives, the cautionary narrative questions the appropriateness of 'private sector' values and mechanisms in the field of public services. A number of authors suggest that SIBs represent a further extension of neoliberal logic in public policy (Warner, 2012; 2013; Whitfield, 2012; McHugh et al, 2013; Malcolmson, 2014; Sinclair et al, 2014). Lake (2015), for example, draws on the notion of financialization to highlight the destructive potential of SIB logic in urban policy making in the US. Financialization is the process whereby both macroeconomic and public policy making are subordinated to financial sector interests. In this way, public policy simply exists to support, stabilise, or expand the economy rather than to meet social needs (Lake, 2015). For a number of authors, SIBs represent the inappropriate intrusion of private sector and financialized values in social policy, and a reversion to pre-welfare state methods of service funding and provision. Dowling and Harvie (2014) discuss the rise of SIBs in the context of the 2010-15 UK government's Big Society agenda. These voices are also critical of the financial and intermediary organisations at the vanguard of 'venture philanthropy' and the way that the SIB social investment model utilises (often unpaid) charitable work for social ends whilst also pursuing profit for investors (Dowling and Harvie, 2014).

SIBs are also criticised for diminishing transparency in the use of public funds. Warner (2012) emphasises the relative 'openness' of public sector contract making and contrasts this with the closed nature of private sector contracts like SIBs that are not publicly disclosed for reasons of commercial sensitivity. She suggests that a degree of public oversight is essential to ensure accountability to citizens and taxpayers in relation to these contracts, as private sector investors or providers may place profit motives above the interests of service recipients. Others have expressed concerns that allowing private financiers to foster a competitive ethos and introduce performance management regimes to non-profit and 
voluntary sector provider organisations may lead to a diminution, or distortion, of their social mission (Joy and Shields, 2013). These critics also stress that, in the worst case, these contracts may be a precursor to the full privatisation of service provision and can diminish the advocacy roles that non-profit organisations play in civil society because a reliance on long-term government sanctioned contracts may ultimately impinge on their independence (McHugh et al, 2013; Whitfield, 2012; Joy and Shields, 2013).

For the most part, the cautionary narrative is favourably disposed, in principle, to the focus on outcomes-based contracting central to SIBs. Fox and Albertson have written extensively on SIBs and their application to the criminal justice sector and probation services in the UK (Fox and Albertson, 2011; 2012; Fox, Albertson \& Wong, 2013), and suggest that a strength of SIBs is that, by reducing reliance on process measurement, they challenge the output 'target culture' associated with the NPM. Indeed, from this perspective, the shift from process to outcome measures aligns SIBs to an 'evidence based' approach where what matters is what works (Deering, 2014). However, there is recognition that outcome measures need to be very carefully defined and calibrated by commissioners, providers, and investors (Warner, 2012; 2013). The focus on measurement also raises significant questions about the attribution of outcomes to the actions of providers and financiers, and how any 'SIB effect' can adequately be interpreted and validated (Fox and Albertson, 2011; Fitzgerald, 2013; McHugh et al, 2013; Sinclair et al, 2014).

Finally, the cautionary narrative emphasises the problems inherent in calculating risk in SIB contracts. McKay (2013a; 2013b) evaluated a number of risk-cost scenarios in a proposed SIB in Maryland aimed at reducing recidivism, and concluded that, in this setting, the 
government would increase operational risks by using a SIB model through increased transactions costs and greater contractual complexity. Pauly and Swanson (2013) suggest that risk calculations are likely to be highly context-specific, making it difficult to benefit from the accumulation of past experience in SIB investing, thereby maintaining the complexity of the process of establishing SIBs. SIB projects in the UK have benefited from government support - for example, through the Social Outcomes Fund, Commissioning Better Outcomes Fund, Fair Chance Fund, Innovation Fund and Youth Engagement Fund (Cabinet Office, 2015). Famously, the New York Rikers Island SIB project was underwritten by Bloomberg philanthropy in order to secure Goldman Sachs' investment (Warner, 2012). This suggests that private sector investors may be more risk-averse than some SIB proponents have claimed and are likely to require government or philanthropic funds to guarantee, or underwrite their investment, to reduce their financial risk if they choose to invest in a SIB.

\section{Early Empirical findings}

In this section, we report findings from 14 mainly qualitative studies reporting on SIB projects, mostly from the UK and the US (see Appendix 3 for details of actual and prospective SIB projects described). Many of these early empirical studies were funded by government agencies keen to explore SIBs as an innovative option for public sector reform. Reflecting this, the studies are largely framed within the public sector reform narrative in that they focus on how services funded through a SIB may foster innovation and improvements in outcomes in policy areas where previous public or non-profit and voluntary sector provision was deemed problematic. 
The process evaluations of SIBs in different countries and policy areas have identified a considerable number of challenges associated with setting up SIBs and establishing outcomes-based contracts. First, they frequently point to the difficulty of agreeing what should be measured in the contracts - by whom and how often - as well as the length of time needed to establish SIB contracts among the parties involved (KPMG, 2014; Tan et al, 2015; DWP, 2014; DCLG, 2014; 2015; Disley et al, 2011). This literature reflects on the potential difficulties of the negotiations surrounding SIB outcomes-based contracts. These challenges are attributed to a combination of: the intrinsic complexity of SIBs; the novelty of the process; how SIBs often involve innovative services; and the fact that contracting for outcomes raises new issues for the actors involved and requires substantial discussions to account for all possible contingencies. The reports on the SIB at Peterborough Prison in the UK highlighted the extent of the discussions that continued even after the contract had been signed (Disley et al, 2011; Disley and Rubin, 2014), specifically relating to the statistical methods used to measure outcomes, the definition of the beneficiaries, the limitations of the data on outcomes (Jolliffe and Hederman, 2014), and the need to account for changing circumstances over time (Disley et al, 2011; Disley and Rubin, 2014). More recent empirical studies of UK pilot SIBs suggest that robust counterfactual groups are often hard to find and thus not prevalent in approaches to evaluating or measuring their outcomes (Tan et al, 2015; DWP, 2014). This has also been highlighted as a growing problem for SIB development in the US (Butler et al, 2013).

\section{Discussion}

This review has brought together the academic and 'grey' literature on SIBs from highincome countries in the form of an interpretive synthesis. Overall, there is a paucity of 
evidence about SIBs - most of the material identified is best described as commentary. Nevertheless, we identified three main themes in the 101 sources which met the inclusion criteria - the role of public versus private values, the importance of outcomes contracting, and the problematic nature of calculating and allocating risk for SIB projects. We also identified three distinct narratives in the literature on SIBs - a public sector reform narrative, a private financial sector reform narrative and a cautionary narrative. The small number of predominantly qualitative empirical studies of SIB projects (under development and signed) focused on difficulties in establishing SIBs and determining measurable outcomes. In this final section, we reflect on the appeal of SIBs for policymakers and analyse the respective plausibility and relative logic of each of our three identified narratives; next, we question what the enthusiasm of policymakers may overlook; and, finally, we highlight issues that policymakers may wish to consider carefully as SIBs develop.

In recent years, SIBs have spread across a range of public policy domains in a number of countries, promoted on the basis that they can offer 'win-win' solutions to governments, investors, service providers and service users. The appeal of SIBs as a financing mechanism aligns with the wider public sector reform goals of the NPM movement (Warner, 2012). Paying for outcomes achieved rather than relying on process measures or upfront payments for services delivered is part of a longer term trend to increase accountability through reimbursement tools that enable explicit performance measurement. Furthermore, for its proponents, the SIB represents a fresh alignment or collaboration between private finance, non-government providers and public service commissioners which cuts through traditional public, private and non-profit barriers (Callanan and Law, 2012). For policymakers, the logic of the SIB lies in the potential it may hold to foster greater financial sector involvement with 
respect to both financing and knowledge exchange to augment public and non-profit service delivery.

In the absence of much empirical data, very little quantitative evaluation of impacts versus the status quo and the fact that most operational SIBs are in the early implementation stage, we are left to assess the respective plausibility of each these narratives from what is already known in related fields. The public sector reform narrative can appear plausible (for example, to policy makers and commissioners of services) provided one is confident in the superior effectiveness of third and private sector providers and the superiority of outcome-based contracts over more conventional forms. However, the evidence suggests that use of other than public sector providers is no guarantee of superior performance (Dunleavy et al, 2006) and that performance-related contracts have mixed success (NAO, 2015). The financial sector reform narrative is likely to underestimate the tension between the aims and objectives of 'finance first' and 'impact first' investment models, as well as the many challenges involved in tackling complex social problems, which may not necessarily be solved more cost-effectively by better management or private sector expertise.

By contrast, the cautionary narrative emanating mostly from actors not directly party to SIB market development, is currently closest to the limited evidence available (Tan et al, 2015) since it identifies the new challenges created by SIBs which can be seen in the research on SIB implementation. While private financing via SIBs might help commissioners manage the financial risks associated with commissioning innovative responses to embedded social problems, they are still faced with the operational and reputational risks associated with 
failure since the responsibility for tackling these issues ultimately rests with the public commissioner. From this perspective, the benefits of SIBs may be more limited than anticipated.

The enthusiasm some policymakers have for SIBs may overlook some problematic issues with the policy. Firstly, as highlighted above, performance-related funding of service providers is no panacea for poor service delivery $(\mathrm{NAO}, 2015)$ and there is limited empirical evidence that payment for performance or payment by results delivers better outcomes than conventional reimbursement methods when applied to public services (Lagarde et al, 2013). This has been explored in health at the primary (Campbell et al, 2007) and secondary health care level (Kristensen et al, 2013), and also in education (Podgursky \& Springer 2007). There is also much evidence on UK government outsourcing and subcontracting that highlights serious failures therein (King \& Crewe, 2014). Furthermore, authors such as Mazzucato (2013) highlight the relative superiority of the public sector to innovate and take risks. Secondly, it is possible that over time, outcome measures may develop their own 'tyrannical' implications just as process measures did for professionals and service providers previously, where the need to work towards specified outcome metrics may come to be seen as targets that dominate performance management regimes. Thirdly, as already highlighted in the early SIBs, there is potential for creaming or more explicit 'gaming' (DWP, 2014), especially if outcomes or the target population are not carefully specified in a SIB contract. Fourthly, SIBs may side-line service user interests and pose questions around democratic accountability (Joy and Shields, 2013; Warner, 2013). Finally, it is not known what the impact of financial incentives will be on service delivery organisations, particularly on the organisational missions or ethos of non-profit service providers (Joy and Shields, 2013), 
however, there is reason to be circumspect (Stout, 2014). Furthermore, whilst commissioners can indeed defer payments for services using SIBs - they will still have to budget to pay in the end since they cannot guarantee that savings equal to the outcome premia will necessarily be realised even if outcome targets are met - and might (as with the PFI experience in the UK) end up paying more than if they had commissioned the service in a more conventional way. Many of the savings in SIB schemes appear to be based on hypothetical rather than real cost reductions, are complicated to calculate and in the absence of (quasi) experimental impact evaluations, hard to attribute (Tan et al, 2015).

Given these issues, it remains important that policymakers considering a SIB contract make a realistic ex ante assessment of the likely benefits and drawbacks of a SIB in each case rather than assuming that any SIB will deliver a 'win-win' solution (Giacomantonio, forthcoming). To date, across all active SIBs, there has been very little rigorous counterfactual comparison of SIBs versus alternative methods of finance to deliver the same service to the same type of users, and thus a lack of evidence of costs and benefits compared with the alternative approach to procurement. Given that SIBs are expected to bring more rigour in measurement and performance monitoring to the non-profit and voluntary sector, the lack of quantitative data and evidenced cashable savings is worrisome. It is hoped that the future implementation of SIBs will allow researchers to assess whether, and, if so, the extent to which SIBs bring about the benefits espoused by their proponents and how this is done. This may be achieved through longitudinal comparative mixed-method studies of the same services provided by the same providers through SIB and non-SIB funding mechanisms, for example, by drawing on in depth qualitative interviews with service users, provider organisations, commissioners, intermediaries and investors. It will also require detailed examination of SIB contracts and access to high quality quantitative data about the target population, and ideally, also a 
counterfactual group, and where possible, randomised controlled trials (RCTs). There is a need for careful ex ante consideration of the complex balance of risks, drawbacks and benefits in each case, and far more empirical studies ex post. 


\section{References}

Addaction (2012), A better future for families: the importance of family based interventions in tackling substance misuse. Available at: http://docplayer.net/2817028-Breaking-the-cyclea-better-future-for-families-the-importance-of-family-based-interventions-in-tacklingsubstance-misuse.html (Accessed 31 May 2016).

Antadze, N., \& Westley, F. R. (2012), Impact Metrics for Social Innovation: Barriers or Bridges to Radical Change? Journal of Social Entrepreneurship, 3(2), 133-150.

Aylott, M., \& Shelupanov, A. (2011), Social Impact Bonds in Criminal Justice: From Interesting Idea to Business as Usual. Prison Service Journal, 195, 3-8.

Bafford, B. (2012), The Feasibility and Future of Social Impact Bonds in the United States. Sanford Journal of Public Policy, 3 (1), 3-19.

Baliga, S. (2013), Shaping the Success of Social Impact Bonds in the United States: Lessons Learned from the Privatization of US Prisons. Duke LJ, 63, 437-479.

Barajas, A., Barajas, L., Burt, K., Harper Jr, T., Johnson, P., Larsen, E., Licona, J., Nije, C. O., Parker, W., Reid, K., Sturtevant, L., Tokunaga, M., Vien, Q., \& Yeh, C. (2014), Social Impact Bonds: A new tool for social financing. PPIA Program, Princeton University.

Beck Jørgensen, T.B., \& B. Bozeman . (2007), The Public Values Universe: An Inventory. Administration and Society, 39, 3, $354-81$.

Broughton, N., Keohane, N., \& Shorthouse, R. (2012), A future state of mind: facing up to the dementia challenge. The Social Market Foundation, London.

Bugg-Levine, A., \& Emerson, J. (2011), Impact investing: Transforming how we make money while making a difference. Innovations, 6(3), 9-18. 
Burand, D. (2012), Globalizing Social Finance: How Social Impact Bonds and Social Impact Performance Guarantees Can Scale Development. NYUJL \& Bus., 9, 447-502.

Butler, D., Bloom, D., \& Rudd, T. (2013), Using Social Impact Bonds to Spur Innovation, Knowledge Building, and Accountability. Community Development Investment Review, 9(1), 53-58.

Cabinet Office (2013), Guidance on the template contract for social impact bonds and payment by results. London. Available at:

https://www.gov.uk/government/publications/guidance-on-the-template-contract-for-socialimpact-bonds (Accessed 31 May 2016).

Cabinet Office (2015), Centre for Social Impact Bonds: Funding. London. Available at: https://data.gov.uk/sib_knowledge box/funding-0 (Accessed 31 May 2016).

Cabinet Office (2016), Centre for Social Impact Bonds: Home. London. Available at: https://data.gov.uk/sib_knowledge_box/

Callanan, L., \& Law, J. (2012), Will social impact bonds work in the United States? McKinsey on Society. Washington DC.

Campbell, S., Reeves, D., Kontopantelis, E., Middleton, E., Sibbald, B., \& Roland, M. (2007), Quality of primary care in England with the introduction of pay for performance. New England Journal of Medicine, 357(2), 181-190.

Cheney, A. L., Merchant, K. E., \& Killins Jr, R. (2012), Impact Investing: A 21st century tool to attract and retain donors. The Foundation Review, 4(4), 45-56.

Clark, M., David Jr, C. C., Hwang, J., Moses, N., Nelson, S., \& Torres, N. D. (2014), NextGeneration Nonprofits. in Hansen-Turton, T. \& Torres, N. D. (eds) Social Innovation and Impact in Nonprofit Leadership, Springer, New York. 63-81. 
Clay, R. F. (2013), Health impact bonds: will investors pay for intervention? Environmental health perspectives, 121(2), a45.

Clifford, J., Markey, K., \& Malpani, N. (2013), Measuring Social Impact in Social Enterprise: The state of thought and practice in the UK. London. E3M. Available at http://can-

online.org.uk/uploads/editor/files/Invest/Measuring_Social_Impact_in_Social_Enterprise_rep ort.pdf (Accessed 31 May 2016).

Cohen, R. (2011), Harnessing social entrepreneurship and investment to bridge the social divide. In EU conference on the social economy (Vol. 18).

Corrigan, P. (2013), Social impact bonds: a new way to invest in better health care. Social Finance, London.

Cox, B. R. (2011), Financing Homelessness Prevention Programs with Social Impact Bonds. Rev. Banking \& Fin. L., 31, 959-985.

Crowley, D. M. (2014), The Role of Social Impact Bonds in Pediatric Health Care.

Pediatrics, 134(2), e331-e333.

Dagher Jr, P. G. (2013), Social Impact Bonds and the Private Benefit Doctrine: Will Participation Jeopardize a Nonprofit's Tax-Exempt Status. Fordham L. Rev. 81, 3479-3519.

DCLG (2014), Qualitative Evaluation of the London Homelessness Social Impact Bond: First Interim Report. London. Available at:

https://www.gov.uk/government/uploads/system/uploads/attachment_data/file/357785/Qualit ative_Evaluation_of the_London_Homelessness_SIB.pdf (Accessed 31 May 2016).

DCLG (2015), Qualitative Evaluation of the London Homelessness Social Impact Bond: Second Interim Report. London. Available at: 
https://www.london.gov.uk/sites/default/files/Qualitative\%20evaluation\%20of\%20the\%20Lo ndon\%20homelessness\%20SIB\%20Second\%20interim\%20report.pdf (Accessed 31 May 2016).

Dunleavy, P., Margetts, H., Bastow, S., \& Tinkler, J. (2006), New public management is dead-long live digital-era governance. Journal of Public Administration Research and Theory 16, no. 3 467-494.

DWP (2014), Innovation Fund Pilots Qualitative Evaluation: Early Implementation Findings. London. Available at:

https://www.gov.uk/government/uploads/system/uploads/attachment_data/file/329168/ifpilots-qual-eval-report-880.pdf (Accessed 31 May 2016).

Deering, J. (2014), A Future for Probation? The Howard Journal of Criminal Justice, 53(1), $1-15$.

Demel, A. (2012), Second Thoughts on Social Impact Bonds. NYUJL \& Bus., 9, 503-509.

Disley, E., Rubin, J., Scraggs, E., Burrowes, N., \& Culley, D. M. (2011), Evaluation of the Social Impact Bond. RAND, Cambridge.

Disley, E. \& Rubin, J. (2014), Phase 2 report from the payment by results Social Impact Bond pilot at HMP Peterborough. RAND, Cambridge.

Dixon-Woods, M., Bonas, S., Booth, A., Jones, D. R., Miller, T., Smith, J., Sutton, A. J., \& Young, B. (2006), How can systematic reviews incorporate qualitative research? A critical perspective. Qualitative Research, 6(1), 27-44.

Dodd, J. A., \& Moody, R. (2011), Outcomes, Not Process: Towards a New Model for European Funding in an Age of Austerity. Journal of Contemporary European Research, 7(1), 120-128. 
Donaldson, J. (2012), Navigating change: using new crime, health and financial structures to tackle multiple needs and exclusions. MEAM, London. Available at: http://meam.org.uk/wpcontent/uploads/2012/07/Emerging-Structures-FINAL.pdf (Accessed 31 May 2016).

Dowling, E., \& Harvie, D. (2014), Harnessing the Social: State, Crisis and (Big) Society. Sociology, 48(5), 869-886.

Dugger, R., \& Litan, R. (2012), Early childhood "pay-for-success" social impact finance: A PKSE bond example to increase school readiness and reduce special education costs. A Report of the Kauffman Foundation and Ready Nation Working Group on Early Childhood Finance Innovation.

Eames, S., Terranova, V., Battaglia, L., Nelson, I., Riesenberg, C., \& Rosales, L. (2014), A Review of Social Impact Bonds: Financing Social Service Programs through Public-Private Partnerships (No. 02). Working Paper. Available at: https://www.businessaccess.com/_resources/_docs/impact/AReviewofSocialImpactBonds.pdf (Accessed 31 May 2016).

Ferlie, E., Ashburner, L., Fitzgerald, L., Pettigrew, A. (1996), The new public management in action. Oxford University Press, Oxford

Fitzgerald, J. L. (2013), Social impact bonds and their application to preventive health. Australian Health Review, 37(2), 199-204.

Fitzpatrick, R., \& Thorne, L. (2010), A label for exclusion: Support for alcohol-misusing offenders. Centre for Mental Health Policy Paper. London.

Fox, C., \& Albertson, K. (2011), Payment by results and social impact bonds in the criminal justice sector: New challenges for the concept of evidence-based policy? Criminology and Criminal Justice, Vol 11, No 5, 395-413. 
Fox, C., \& Albertson, K. (2012), Is payment by results the most efficient way to address the challenges faced by the criminal justice sector? Probation Journal, 59(4), 355-373. Fox, C., Albertson, K., \& Wong, K. (2013), Justice Reinvestment: Can the criminal justice system deliver more for less? Routledge. London.

Galloway, I. (2014), Using pay-for-success to increase investment in the nonmedical determinants of health. Health Affairs, 33(11), 1897-1904.

Giacomantonio, C. (forthcoming), Grant-maximising but not money-making: A simple decision-tree analysis for Social Impact Bonds.

Goodall, E. (2014), Choosing Social Impact Bonds: A Practitioner's Guide. Bridges Ventures, London.

Griffiths, A., \& Meinicke, C. (2014), Introduction to social impact bonds and early intervention. Early Intervention Foundation, London. Available at: http://cdn.basw.co.uk/upload/basw_42717-3.pdf (Accessed 31 May 2016).

Haffar, T. (2014), Communicating Value in Social Impact Bonds: The Role Of The Intermediary. MA thesis Cornell University.

Hetherington, D. (2013), Social innovation, public good: new approaches to public sector productivity. Per Capita, Australia. Available at: http://apo.org.au/research/social-innovationpublic-good-new-approaches-public-sector-productivity (Accessed 31 May 2016).

HM Government (2011), Growing the Social Investment Market: a vision and a strategy. London. Available at: https://www.gov.uk/government/uploads/system/uploads/attachment_data/file/61185/404970 _SocialInvestmentMarket_acc.pdf (Accessed 31 May 2016). 
HM Government (2013), Open Public Services. London. Available at:

https://www.gov.uk/government/uploads/system/uploads/attachment_data/file/200077/Open

Public_Services_2013_full_report.pdf (Accessed 31 May 2016).

Hood, C. (1991), A public management for all seasons?. Public Administration, 69(1), 3-19.

Horne, M., Khan, H., \& Corrigan, P. (2013), People powered health: health for people, by people and with people. Nesta, London.

Humphries, K. W. (2013), Not Your Older Brother's Bonds: The Use and Regulation of Social-Impact Bonds in the United States. Law \& Contemp. Probs., 76, 433-452.

Jackson, E. T. (2013), Evaluating social impact bonds: questions, challenges, innovations, and possibilities in measuring outcomes in impact investing. Community Development, 44:5, 608-616

Jolliffe, D., \& Hedderman, C. (2014), Peterborough Social impact bond: final report on cohort 1 analysis. : Ministry of Justice. London.

Joy, I., de Las Casas, L., Rickey, B., \& Capital, N. P. (2011), Understanding the demand for and supply of social finance. London: New Philanthropy Capital.

Joy, M., \& Shields, J. (2013), Social Impact Bonds: The Next Phase of Third Sector marketization? Canadian journal of nonprofit and social economy research, 4(2) 39-55.

Kanders, K. (2013), When high finance meets age-old problems. Communities \& Banking. Federal Reserve Bank of Boston, Winter, 28-29.

King, A., \& Crewe, I. (2014), The blunders of our governments. Oneworld Publications.

KPMG (2014), Evaluation of the Joint Development Phase of the NSW Social Benefit Bonds Trial. Government Advisory Service, New South Wales. Available at: 
http://www.benevolent.org.au/ /media/Benevolent/About/KPMG_Evaluation_SBB_JDP_Fin al_Report_290114\%20pdf.ashx (Accessed 31 May 2016).

Kristensen, S.R., McDonald, R., and Sutton, M. (2013), Should pay-for-performance schemes be locally designed? Evidence from the commissioning for quality and innovation (CQUIN) framework. Journal of health services research \& policy, 18 (2 suppl), pp.38-49.

Lake, R. W. (2015), The financialization of urban policy in the age of Obama. Journal of Urban Affairs, 37(1), 75-78.

Lagarde, M., Wright, M., Nossiter, J., \& Mays, N. (2013), Challenges of payment-forperformance in health care and other public services-design, implementation and evaluation. PIRU Publication. London.

Langford, A. R. (2011), Social impact bonds in Canada: From theory to implementation. MA Thesis, Simon Fraser University.

Lehner, O. M., \& Brandstetter, L. (2014), Impact Investment Portfolios: Including Social Risks and Returns. ACRN Oxford Publishing House: Oxford UK. Available at SSRN: http://ssrn.com/abstract=2519671. (Accessed 31 May 2016).

Leventhal, R. (2012), Effecting Progress: Using Social Impact Bonds to Finance Social Services. NYUJL \& Bus., 9, 511-534.

Liang, M., Mansberger, B., \& Spieler, A. C. (2014), An Overview of Social Impact Bonds.. J. Int'l Bus. \& L., 13, 267-281.

Liebman, J. B. (2011), Social Impact Bonds: A promising new financing model to accelerate social innovation and improve government performance. Center for American Progress, Washington D.C. 
Local Government Association and Social Finance (2013), An introduction to social investment. Available at:

http://www.local.gov.uk/c/document_library/get_file?uuid=5e51e4e3-8d18-41f1-a55a4f95979b52bd (Accessed 31 May 2016).

Loder, J., Mulgan, G., Reeder, N., \& Shelupanov, A. (2010), Financing social value: implementing social impact bonds. Young Foundation, London

Loder, J. (2011), 'The Promise of Social Impact Bonds.' Social Space, 42-47.

Loder, J., Jones, G. R., \& Norman, W. (2013), Social Investment in Education. Young Foundation London.

Malcolmson, J. D. (2014), Social impact bonds: cleared for landing in British Columbia.

CUPE Research. Available at: https://cupe.ca/sites/cupe/files/Research_note-

_SIBs_come_to_BC.pdf (Accessed 31 May 2016).

Marsh, K., Bertranou, E., \& Samanta, K. (2011), Cost-benefit analysis and social impact bond feasibility analysis for the Birmingham Be Active scheme. Matrix Evidence. Available at: http://www.optimitymatrix.com/wp-content/uploads/2013/09/28-Matrix_Be-Active_Finalreport.pdf (Accessed 31 May 2016).

Martin, M. (2013), Making Impact Investible. Impact Economy Working Papers Vol 4 Mazzucato, M. (2013), The Entrepreneurial State: Debunking public vs. private sector myths. Anthem Press. London.

McKay, K. (2013a), Evaluating Social Impact Bonds as a New Reentry Financing Mechanism: A Case Study on Reentry Programming in Maryland. Available at: http://mgaleg.maryland.gov/Pubs/BudgetFiscal/2013-Evaluating-Social-Impact-Bonds.pdf (Accessed 31 May 2016). 
McKay, K. (2013b), Debunking the myths behind social impact bond speculation. Stanford Social Innovation Review April. Available at:

http://ssir.org/articles/entry/debunking_the_myths_behind_social_impact_bond_speculation (Accessed 31 May 2016).

Mosenson, S. H. (2013), New models of private sector financing of not-for-profit corporations Doctoral dissertation, Northeastern University Boston.

McHugh, N., Sinclair, S., Roy, M., Huckfield, L., \& Donaldson, C. (2013), Social impact bonds: a wolf in sheep's clothing? Journal of Poverty and Social Justice, 21(3), 247-257.

Moore, M. L., Westley, F. R., \& Nicholls, A. (2012), The Social Finance and Social Innovation Nexus. Journal of Social Entrepreneurship, 3(2), 115-132.

Mulgan, G., Reeder, N., Aylott, M., \& Bo'sher, L. (2011), Social impact investment: the challenge and opportunity of social impact bonds. Young Foundation. London.

Mullins, D., Rees, J., \& Meek, R. (2011), Open public services and the third sector: what's the evidence?. Centre for Market and Public Organisation. Research in Public Policy.13, 1517

National Audit Office (NAO) (2015), Outcome-based payment schemes: government's use of payment by results. London. Available at: https://www.nao.org.uk/wp-

content/uploads/2015/06/Outcome-based-payment-schemes-governments-use-of-paymentby-results.pdf (Accessed 31 May 2016).

New Philanthropy Capital (2010), Manifesto for social impact. New Philanthropy Capital, London 
Nicholls, A. \& Murdock, A. (2012), The nature of social innovation. In Nicholls, A. \& Murdock, A. (eds) Social innovation: Blurring boundaries to reconfigure markets, Palgrave Macmillan, London. 1-32.

Nicholls, A. (2013), Filling the Capital Gap. In: Denny, S. and Seddon, F., (eds.) Social Enterprise: Accountability and Evaluation around the World. Routledge, 161-195

Noordegraaf, M., \& Abma, T. (2003),Management by Measurement? Public Management Practices Amidst Ambiguity, Public Administration, 81, 4, 853 - 871.

Pauly, M., \& Swanson, A. (2013), Social Impact Bonds in Nonprofit Health Care: New Product or New Package? (No. w18991). National Bureau of Economic Research. Avaialable at: http://www.nber.org/papers/w18991 (Accessed 31 May 2016).

Petrick, S. (2013), Impact Investing in the area of long-term unemployment. Social Venture Fund, London. Available at: http://impetus-pef.org.uk/wp-content/uploads/2013/10/Impactinvesting-in-the-area-of-longterm-employment.pdf (Accessed 31 May 2016).

Podgursky, M. J., \& Springer, M. G. (2007), Teacher performance pay: A review. Journal of Policy Analysis and Management, 26(4), 909-949.

Porter, M. E., \& Kramer, M. R. (2006), The link between competitive advantage and corporate social responsibility. Harvard business review, 84(12), 78-92.

Power, M. (1999), The audit society: Rituals of verification. OUP. Oxford.

Roberts, M. (2013), Fulfilling lives: a guide to the new policy environment for multiple needs. MEAM, London.

Roe, D. (2011), Cost \& Cost-Effectiveness Issues in Learning Disabilities Social Care Provision. Laing \& Buisson, London. 
Rotheroe, A., Joy, I., \& Lomax, P. (2013), Allia's Future for Children Bond: Lessons learned. New Philanthropy Capital, London. Available at: http://www.thinknpc.org/publications/thefuture-for-children-bond-lessons-learned (Accessed 31 May 2016).

Rudd, T., Nicoletti, E., Misner, K., \& Bonsu, J. (2013), Financing Promising Evidence-Based Programs: Early Lessons from the New York City Social Impact Bond. MDRC. New York. Available at: http://www.mdrc.org/publication/financing-promising-evidence-basedprograms/file-full (Accessed 31 May 2016).

Scherer, J., \& Schenk, L (2012), Advancing social impact measurement to build an asset class: the appeal of social impact bonds. Community Investments, (Spr), 10-13.

Seymour, L. (2010), Public health and criminal justice: promoting and protecting offenders' mental health and wellbeing. Centre for Mental Health, London.

Shiller, R. J. (2013), Capitalism and Financial Innovation. Financial Analysts Journal, 69(1). 21-25.

Sinclair, S., McHugh, N., Huckfield, L., Roy, M., \& Donaldson, C. (2014), Social Impact Bonds: shifting the boundaries of citizenship. In Farnsworth, K. Irving, Z. \& Fenger, M. (eds) Social Policy Review 26: Analysis and Debate in Social Policy, 119-136.

Social Enterprise UK (2013), The power of partnerships: effective working with the voluntary, community and social enterprise sector to achieve local health goals. Social Enterprise UK, London. Available at: http://www.socialenterprise.org.uk/uploads/files/2013/06/powerpartnershiptoolkit_onlinefeb1 3.pdf (Accessed 31 May 2016).

Social Finance (2011a), Social Impact Bonds, the one service, one year on: Overview of the Peterborough Social Impact Bond. Social Finance, London. Available at: 
http://www.socialfinance.org.uk/social-impact-bonds-the-one-service-one-year-on/ (Accessed

31 May 2016).

Social Finance (2011b), A technical guide to developing a social impact bond: vulnerable children and young people, Social Finance. London. Available at:

http://www.socialfinanceus.org/sites/socialfinanceus.org/files/Technical_Guide_Vulnerable

Children.pdf (Accessed 31 May 2016).

Social Innovation Exchange and the Young Foundation (2010), Study on social innovation.

European Union \& The Young Foundation. London. Available at:

http://youngfoundation.org/wp-content/uploads/2012/10/Study-on-Social-Innovation-for-the-

Bureau-of-European-Policy-Advisors-March-2010.pdf (Accessed 31 May 2016).

Social Investment Task Force (2010), Social investment ten years on. Social Investment Task

Force. London. Available at: http://www.makehope.org/wp-

content/uploads/old/1292754218.pdf (Accessed 31 May 2016).

Stoesz, D. (2014), Evidence-Based Policy Reorganizing Social Services Through Accountable Care Organizations and Social Impact Bonds. Research on Social Work Practice, 24(2), 181-185.

Stout, L. (2014), Killing Conscience: The Unintended Behavioral Consequences of 'Pay For Performance' Journal of Corporation Law, Vol. 39, Issue 1; Cornell Legal Studies Research Paper No. 14-06. Available at SSRN: http://ssrn.com/abstract=2407096 (Accessed 31 May 2016).

Sussex, J. (2001), The economics of the private finance initiative in the NHS. Office of Health Economics. London. 
Tan, S., Fraser, A., Giacomantonio, C., Kruithof, K., Sim, M., Lagarde, M., Disley, E., Rubin, J., \& Mays, N. (2015), An evaluation of Social Impact Bonds in Health and Social Care. PIRU, London School of Hygiene \& Tropical Medicine \& RAND Europe

Thomas, H. (2013), Understanding commissioning and procurement: a guide for local compacts. Compact Voice. London. Available at:

http://www.supporthub.org.uk/sites/supporthub.org.uk/files/CVoiceunderstanding_commissioning_and_procurement_guide-jul13.pdf (Accessed 31 May 2016).

Tran, M. P. (2014), Social Impact Bonds Gain Momentum in the Criminal Justice Field. Justice Center. London. Available at: https://csgjusticecenter.org/reentry/posts/social-impactbonds-gain-momentum-in-the-criminal-justice-field/ (Accessed 31 May 2016).

Trupin, E., Weiss, N., \& Kerns, S. E. (2014), Social impact bonds: behavioral health opportunities. JAMA Pediatrics, 168(11), 985-986.

Van der Wal, Z., De Graaf, G., \& Lasthuizen, K. (2008), What's valued most? Similarities and differences between the organizational values of the public and private sector. Public Administration, 86(2), 465-482.

Vanderwal, P. (2015), Rising private investment in EMs provides opportunities for new financing mechanisms. The Economic Times. [09/06/2015]. Available at: http://economictimes.indiatimes.com/opinion/interviews/rising-private-investment-in-emsprovides-opportunities-for-new-financing-mechanisms-petervanderwal/articleshow/47604141.cms

Von Glahn, D. \& Whistler, C. (2011a), Pay for success programs: an introduction. Policy \& Practice: 20, 19-22. 
Von Glahn, D. \& Whistler, C. (2011b), Translating plain English: can the Peterborough Social Impact Bond construct apply stateside? Community Development Investment Review, $58-70$.

Watson, G.W., Papamarcos, S. D., Teague, B. T., \& Bean, C. (2004), Exploring the Dynamics of Business Values: A Self-Affirmation Perspective. Journal of Business Ethics, $49,4,337-346$.

Warner, M. (2012), Profiting from Public Value? The Case of Social Impact Bonds. Draft paper prepared for Creating Public Value Conference, University of Minnesota, September.

Warner, M. E. (2013), Private finance for public goods: social impact bonds. Journal of Economic Policy Reform, 16(4), 303-319.

Whitfield, D. (2012), The payment-by-results road to marketization. In Silvestri, A. (ed) Critical reflections: social and criminal justice in the first year of Coalition government, Centre for Crime \& Justice Studies, London. 22-23.

Wilson, K. E. (2014), Social Investment: New Investment Approaches for Addressing Social and Economic Challenges. OECD Library, Paris.

Young Foundation and NESTA (2011), Growing Social Ventures: the role of intermediaries and investors - who they are, what they do, and what they could become. Young Foundation \& NESTA, London. Available at: http://youngfoundation.org/wpcontent/uploads/2012/10/Growing-Social-Ventures-2011.pdf (Accessed 31 May 2016). 
Table 1: Search strategy for literature review

\begin{tabular}{|l|l|}
\hline Search terms & Databases searched \\
\hline "social impact bond" & IBSS, CINAHL, Cochrane Library, \\
social AND impact AND bond & EMBASE, ERIC, Ethos, Global Health, \\
"pay* for success bond*" & GreenFILE, Health Systems Evidence, \\
"pay* for success contract*" & HEED, HMIC, NCJRS, NBER, NICE \\
"impact invest*" & (evidence search), Open Grey, Pubmed, \\
"impact-first invest*" & Scopus, Social Policy \& Practice, Web of \\
"social innovation financ*" & Science, Google Scholar \\
"health impact bond*" & \\
"social impact invest*" & \\
"social benefit bond" & \\
"social bond" & \\
\hline
\end{tabular}


Appendix 1: Academic papers included in the review

\begin{tabular}{|c|c|c|c|}
\hline $\begin{array}{l}\text { Narrative/ } \\
\text { Concept }\end{array}$ & Public sector reform narrative & Financial sector reform narrative & Cautionary narrative \\
\hline Values & $\begin{array}{l}\text { Cox (2011) } \\
\text { Leventhal (2012) } \\
\text { Galloway (2014) } \\
\text { Stoesz (2014) }\end{array}$ & $\begin{array}{l}\text { Nicholls (2013) } \\
\text { Leventhal (2012) } \\
\text { Shiller (2013) } \\
\text { Clark et al (2014) } \\
\text { Humphries (2013) } \\
\text { Mosenson (2013) }\end{array}$ & $\begin{array}{l}\text { Warner }(2012 ; 2013) \\
\text { McHugh et al }(2013) \\
\text { Sinclair } \text { et al }(2014) \\
\text { Baliga (2013) } \\
\text { Fox \& Albertson }(2011 ; 2012) \\
\text { Fox, Albertson \& Wong (2013) } \\
\text { Deering (2014) } \\
\text { Demel (2012) } \\
\text { Lake (2015) } \\
\text { Joy \& Shields (2013) } \\
\text { Dowling \& Harvie (2014) }\end{array}$ \\
\hline $\begin{array}{l}\text { Outcomes based } \\
\text { contracts }\end{array}$ & $\begin{array}{l}\text { Fitzgerald (2013) } \\
\text { Cox (2011) } \\
\text { Burand (2012) } \\
\text { Leventhal (2012) } \\
\text { Langford (2011) } \\
\text { Stoesz (2014) }\end{array}$ & $\begin{array}{l}\text { Moore et al (2012) } \\
\text { Leventhal (2012) }\end{array}$ & $\begin{array}{l}\text { Warner }(2012 ; 2013) \\
\text { McHugh et al }(2013) \\
\text { Sinclair } \text { et al }(2014) \\
\text { Fox \& Albertson }(2011 ; 2012) \\
\text { Fox, Albertson \& Wong }(2013) \\
\text { Deering }(2014) \\
\text { Haffar }(2014) \\
\text { Jackson }(2013)\end{array}$ \\
\hline Risk & $\begin{array}{l}\text { Burand (2012) } \\
\text { Leventhal (2012) } \\
\text { Dagher (2013) } \\
\text { Trupin et al (2014) } \\
\text { Crowley (2014) } \\
\text { Dodd \& Moody (2011) } \\
\text { Galloway (2014) } \\
\text { Langford (2011) }\end{array}$ & $\begin{array}{l}\text { Leventhal (2012) } \\
\text { Antadze \& Wesley (2012) } \\
\text { Nicholls (2013) } \\
\text { Shiller (2013) } \\
\text { Lehner \& Brandstetter (2014) } \\
\text { Liang et al(2014) }\end{array}$ & $\begin{array}{l}\text { Warner }(2012 ; 2013) \\
\text { Fox \& Albertson }(2011 ; 2012) \\
\text { Fox, Albertson \& Wong (2013) } \\
\text { Pauly \& Swanson (2013) } \\
\text { Jackson (2013) } \\
\text { McKay (2013b) }\end{array}$ \\
\hline
\end{tabular}


Appendix 2: Grey papers included in the review

Key: 1-Think Tank, 2-Consultancy (including practitioner/intermediary/investment organisations), 3-Government/government affiliated, 4-Civil Society (including voluntary organisations), 5-Other (non-peer reviewed academic reports/short papers/speeches)

\begin{tabular}{|c|c|c|c|c|}
\hline Narrative/ & \multicolumn{2}{|l|}{ Public sector reform narrative } & Financial sector reform narrative & Cautionary narrative \\
\hline Values & $\begin{array}{l}\text { Aylott \& Shelupanov (2011) } 1 \\
\text { Bafford (2012) } 5 \\
\text { Clay (2013) } 5 \\
\text { Cohen (2011) } 5 \\
\text { Social Finance (2011b) } 2 \\
\text { Callanan \& Law (2012) } 2 \\
\text { Mulgan } \text { et al (2011)1 } \\
\text { Social Enterprise UK (2013) } 3 \\
\text { HM Govt (2011; 2013) } 3 \\
\text { Cabinet Office (2013) } 3 \\
\text { Liebman (2011) } 1 \\
\text { Loder } \text { et al (2010) } 2 \\
\text { Loder (2011) 2 } \\
\text { Loder } \text { et al (2013) } 2 \\
\text { Addaction (2012) } 4 \\
\text { Barajas } \text { et al (2014) } 5\end{array}$ & $\begin{array}{l}\text { Horne et al (2013) } 3 \\
\text { Corrigan (2013) } 2 \\
\text { Kanders (2013) } 3 \\
\text { Tran (2014) } 3 \\
\text { Social Innovation Exchange \& Young } \\
\text { Foundation (2010) } 1 \\
\text { Hetherington (2013) } 2 \\
\text { Roe (2011) } 2 \\
\text { Von Glahn \& Whistler (2011a; 2011b) } 5 \\
\text { Petrick (2013) } 2 \\
\text { Donaldson (2012) } 4 \\
\text { Broughton } \text { et al (2012) } 1\end{array}$ & $\begin{array}{l}\text { Mulgan et al (2011) } 1 \\
\text { Callanan \& Law (2012) } 2 \\
\text { Martin (2013) } 2 \\
\text { HM Govt (2011; 2013) } 3 \\
\text { Liebman (2011) } 1 \\
\text { Loder (2011) } 2 \\
\text { Social Finance (2011b) } 2 \\
\text { Von Glahn \& Whistler (2011a; 2011b) } 5 \\
\text { Petrick (2013) } 2 \\
\text { Social Investment Task Force (2010) } 3\end{array}$ & $\begin{array}{l}\text { Whitfield (2012) } 5 \\
\text { Malcolmson (2014) } 4\end{array}$ \\
\hline $\begin{array}{l}\text { Outcomes } \\
\text { based } \\
\text { contracts }\end{array}$ & $\begin{array}{l}\text { Callanan \& Law (2012) } 2 \\
\text { Social Enterprise UK (2013) } 3 \\
\text { Liebman (2011) } 1 \\
\text { Social Finance (2011b) } 2 \\
\text { Bafford (2012) } 5 \\
\text { Local Government Association \& } \\
\text { Social Finance (2013) } 2 \\
\text { New Philanthropy Capital (2010) } 1 \\
\text { Butler } \text { et al (2013) } 3 \\
\text { Fitzpatrick \& Thorne (2010) } 4\end{array}$ & $\begin{array}{l}\text { Griffiths \& Meinke (2014) } 3 \\
\text { Joy } \text { et al (2011) } 1 \\
\text { Seymour (2010) } 4 \\
\text { Roberts (2013) } 4 \\
\text { Thomas (2013) } 3 \\
\text { Eames } \text { et al (2014) } 3 \\
\text { Cheney et al (2012) } 5 \\
\text { Marsh et al (2011) } 2 \\
\text { Clifford } \text { et al (2013) } 2\end{array}$ & $\begin{array}{l}\text { Callanan \& Law (2012) } 2 \\
\text { Liebman (2011) } 1 \\
\text { Wilson (2014) } 3 \\
\text { Scherer \& Schenk (2012) } 3\end{array}$ & \\
\hline Risk & \multicolumn{2}{|c|}{$\begin{array}{l}\text { Callanan \& Law (2012) } 2 \\
\text { Liebman (2011) } 1 \\
\text { Mulgan et al (2011) } 1 \\
\text { Young Foundation \& NESTA (2011) } 1 \\
\text { HM Govt (2013) } 3 \\
\text { Social Enterprise UK (2013) } 3 \\
\text { Bafford (2012) } 5\end{array}$} & $\begin{array}{l}\text { Callanan \& Law (2012) } 2 \\
\text { Liebman (2011) } 1 \\
\text { Young Foundation \& NESTA (2011) } 1 \\
\text { Wilson (2014) } 3\end{array}$ & \\
\hline
\end{tabular}




\begin{tabular}{|c|c|c|c|c|c|}
\hline Author & Year & Title & $\begin{array}{l}\text { Place of } \\
\text { publication }\end{array}$ & Social issue & Study type \\
\hline Disley et al & 2011 & $\begin{array}{l}\text { Lessons learned from the planning and early } \\
\text { implementation of the social impact bond at } \\
\text { HMP Peterborough }\end{array}$ & $\begin{array}{l}\mathrm{UK}(\mathrm{MoJ} \& \\
\text { RAND) }\end{array}$ & Probation/ recidivism & Qualitative \\
\hline $\begin{array}{l}\text { Social } \\
\text { Finance }\end{array}$ & 2011a & $\begin{array}{l}\text { Social Impact Bonds, the one service, one year } \\
\text { on: Overview of the Peterborough Social } \\
\text { Impact Bond }\end{array}$ & $\begin{array}{l}\text { UK (Social } \\
\text { Finance) }\end{array}$ & Probation/ recidivism & Qualitative \\
\hline $\begin{array}{l}\text { Marsh, K. } \\
\text { et al }\end{array}$ & 2011 & $\begin{array}{l}\text { Cost-benefit analysis and social impact bond } \\
\text { feasibility analysis for the Birmingham Be } \\
\text { Active scheme }\end{array}$ & $\begin{array}{l}\text { UK (Matrix } \\
\text { Evidence) }\end{array}$ & Deprivation \& physical activity & $\begin{array}{l}\text { Economic } \\
\text { analysis }\end{array}$ \\
\hline $\begin{array}{l}\text { Dugger, R. } \\
\text { \& Litan, R. }\end{array}$ & 2012 & $\begin{array}{l}\text { Early childhood "pay-for-success" social } \\
\text { impact finance: A PKSE bond example to } \\
\text { increase school readiness and reduce special } \\
\text { education costs }\end{array}$ & $\begin{array}{l}\text { USA (Kauffman } \\
\text { Foundation and } \\
\text { Ready Nation } \\
\text { Working Group } \\
\text { on Early } \\
\text { Childhood } \\
\text { Finance } \\
\text { Innovation) }\end{array}$ & Early years intervention & Qualitative \\
\hline $\begin{array}{l}\text { Rotheroe et } \\
\text { al }\end{array}$ & 2013 & $\begin{array}{l}\text { The future for children bond: identifying the } \\
\text { lessons learned from Allia's bond offer to retail } \\
\text { investors }\end{array}$ & UK (NPC) & Youth care/foster care & Qualitative \\
\hline $\begin{array}{l}\text { Rudd, T. et } \\
\text { al }\end{array}$ & 2013 & $\begin{array}{l}\text { Financing promising evidence-based programs: } \\
\text { early lessons from the New York City social } \\
\text { impact bond }\end{array}$ & USA (MDRC) & Recidivism & Qualitative \\
\hline McKay, K & $2013 a$ & $\begin{array}{l}\text { Evaluating Social Impact Bonds as a New } \\
\text { Reentry Financing Mechanism: A Case Study } \\
\text { on Reentry Programming in Maryland }\end{array}$ & $\begin{array}{l}\text { USA (Maryland } \\
\text { Dept of } \\
\text { Legislative } \\
\text { Services) }\end{array}$ & Recidivism & Qualitative \\
\hline DWP & 2014 & $\begin{array}{l}\text { Innovation Fund Pilots Qualitative Evaluation: } \\
\text { Early Implementation Findings }\end{array}$ & UK (DWP) & $\begin{array}{l}\text { Youth engagement, training } \\
\text { and employment }\end{array}$ & Qualitative \\
\hline $\begin{array}{l}\text { Disley, E. } \\
\text { \& Rubin, J. }\end{array}$ & 2014 & $\begin{array}{l}\text { Phase } 2 \text { report from the payment by results } \\
\text { Social Impact Bond pilot at HMP } \\
\text { Peterborough }\end{array}$ & $\begin{array}{l}\mathrm{UK}(\mathrm{MoJ} \& \\
\text { RAND) }\end{array}$ & Probation/recidivism & Qualitative \\
\hline $\begin{array}{l}\text { Jolliffe \& } \\
\text { Hederman }\end{array}$ & 2014 & $\begin{array}{l}\text { Peterborough Social Impact Bond: Final } \\
\text { Report on Cohort } 1 \text { Analysis }\end{array}$ & $\begin{array}{l}\text { UK ( Qinetiq and } \\
\text { MoJ) }\end{array}$ & Probation/recidivism & Quantitative \\
\hline DCLG & 2014 & $\begin{array}{l}\text { Qualitative Evaluation of the London } \\
\text { Homelessness Social Impact Bond: First } \\
\text { Interim Report }\end{array}$ & UK (DCLG) & Homelessness & Qualitative \\
\hline KPMG & 2014 & $\begin{array}{l}\text { Evaluation of the Joint Development Phase of } \\
\text { the NSW Social Benefit Bonds Trial }\end{array}$ & $\begin{array}{l}\text { Australia ( NSW } \\
\text { Treasury) }\end{array}$ & Youth care/foster care & Qualitative \\
\hline DCLG & 2015 & $\begin{array}{l}\text { Qualitative evaluation of the London } \\
\text { homelessness social impact bond: Second } \\
\text { interim report }\end{array}$ & UK (DCLG) & Homelessness & Qualitative \\
\hline Tan et al & 2015 & $\begin{array}{l}\text { An Evaluation of Social Impact Bonds in } \\
\text { Health and Social Care }\end{array}$ & $\begin{array}{l}\text { UK (PIRU \& } \\
\text { RAND) }\end{array}$ & Health and social care & Qualitative \\
\hline
\end{tabular}

